\title{
ILLNESS CARE AT HOME OR IN HEALTH INSTITUTIONS: THE DECISION PROCESS IN A LOW INCOME COMMUNITY
}

Luiza Akiko Komura Hoga ${ }^{1}$

Hoga LAK. Illness care at home or in health institutions: the decision process in a low income community. Rev Latino-am Enfermagem 2008 janeiro-fevereiro; 16(1):115-21.

The aim of this research was to describe the experiences of a group of women about the decision making process related to illness care at home or in health care institutions. The thematic oral history method was applied. The descriptive categories were: a) The poor have their own way of taking care of health and illness; b) The main support to fight the illness is belief in God; c) Medical care is the last resource, when healing resources are not enough and the illness is dangerous. In low income families, the cultural background, associated to the socioeconomic conditions, permeate the decision with regard to taking care of the illness at home or to seek institutionalized medical care. This knowledge is essential for meaningful health care from the perspective of individuals and families.

DESCRIPTORS: family practice; culture; delivery of health care; socioeconomic factors

\section{CUIDAR DE LA ENFERMEDAD EN CASA O EN INSTITUCIONES DE SALUD: EL PROCESO DE DECISIÓN EN UNA COMUNIDAD CON BAJOS INGRESOS}

El objetivo de la investigación fue describir las experiencias de un grupo de mujeres sobre su decisión de cuidar de la enfermedad en casa o en una institución de asistencia a la salud. Fue utilizado el método de la historia oral temática. Las categorías descriptivas fueron: a) El pobre tiene una forma propia de cuidar de la salud y de la enfermedad; b) El apoyo principal para luchar contra la enfermedad es la creencia en Dios; c) La atención médico es utilizada cuando los recursos de cura no son suficientes y la enfermedad es peligrosa. En familias de bajos ingresos, los conocimientos culturales que están asociados a la condición socioeconómica influyen en el proceso de decisión para cuidar de la enfermedad en casa o buscar una institución para asistencia médica. Este conocimiento es esencial para un cuidado significativo según la perspectiva de las personas y sus familias.

DESCRIPTORES: medicina familiar y comunitária; cultura; prestación de atención de salud; factores socioeconómicos

\section{CUIDADO DA ENFERMIDADE EM CASA OU EM INSTITUIÇÃO DE SAÚDE: O PROCESSO DE DECISÃO EM UMA COMUNIDADE DE BAIXA RENDA}

O objetivo desta pesquisa foi descrever as experiências de um grupo de mulheres relativa ao processo decisório sobre o cuidado da enfermidade no domicílio ou em uma instituição de cuidado à saúde. O método da história oral temática foi desenvolvido. As categorias descritivas foram: a) o pobre possui um jeito próprio de cuidar da saúde e da enfermidade; b) o principal suporte para combater a enfermidade está na crença em Deus; c) O cuidado médico é para quando os recursos de cura não são suficientes e a enfermidade é perigosa. Em famílias de baixa renda, a bagagem cultural que está associada à condição socioeconômica permeia o processo decisório relativo ao cuidar da enfermidade em casa ou buscar o cuidado médico institucionalizado. Este conhecimento é essencial para um cuidado significativo na perspectiva de indivíduos e suas famílias.

DESCRITORES: medicina de família e comunidade; cultura; assistência à saúde; fatores socioeconômicos

${ }^{1}$ Obstetric Nurse. Associate Professor. University of São Paulo School of Nursing, Brazil; email: kikatuca@usp.br 


\section{INTRODUCTION}

The families' health-illness values and convictions need to be understood by health professionals in order to consider their perspective in health care practices. This is a principle of the Family Health Program of the Brazilian Government ${ }^{(1)}$. São Paulo City is a large urban center and attracts families from other states and regions. Internal migration has resulted in a variety of cultural communities in this city. Rio Negro (fictitious name) is one of these communities. During more than a decade of faculty extension activities carried out in that community, it was possible to observe that the health and illness care beliefs, values and practices are shared among family members, their relatives and neighbors.

Among poor families, health care activities are based on a refined socio-cultural guideline and characterized by a high degree of social articulation. There are solidarity and healing strategies, but these are limited by scarcity of financial resources ${ }^{(2)}$. Healing rituals based on their own knowledge are performed in order to solve health problems and these practices are very different from the ones performed by the official health care system ${ }^{(3)}$.

Family health care requires a personalized and contextualized focus on the user's social, ethnic and cultural background ${ }^{(4)}$. Nurses need to see the person as a unique human being interacting with the family and the community ${ }^{(5)}$. What a disease symptom means, when and where to leave ill family members in a medical institution are questions answered according to family beliefs and values ${ }^{(6)}$.

The aim of this research was to describe the experiences of a group of women about the decision making process related to illness care at home or in a health care institution.

\section{METHOD}

Research design

The thematic oral history method was used in this study. The understanding of specific aspects of experience, as well as capturing ideas, values, and beliefs related to the theme, is the essence of this method. Moreover, the method allows people who normally do not have a social voice to express their ideas and feelings ${ }^{(7)}$. Through the thematic oral history it was possible to understand and describe the experiences of each interviewed women regarding their involvement in carrying out illness care at home or to find an appropriate health care institution.

According to the last demographic census carried out in 2000, Rio Negro was composed of 348 families with a total of about 2,152 persons. Living in the community for at least 10 years, demonstration of empathy, having experience on the topic and willingness to report experiences, are some criteria for the inclusion of a person as research collaborator $^{(8)}$. These criteria were followed to include the collaborators in this research.

The identification of the research collaborators, people who have an in-depth knowledge about the studied phenomenon, was facilitated by researcher familiarity with the community. During the health care activities carried out in Rio Negro it was possible to observe that the women were mainly responsible for health, illness and sickness care activities.

The interviews were scheduled by common agreement between the researcher and each woman and carried out in the women's homes, in a room with the presence of the researcher and the collaborator. The following introductory question was presented to each woman: "When a family member becomes ill how do you decide about doing caregiving practices at home or considering the use of a health care institution". Additional questions were incorporated to clarify obscure points and to deepen meaningful content. The data was collected between April and June, 2004, each interview lasting about 60 minutes and being fully recorded and then transcribed verbatim.

Several new collaborators were included, and theoretical saturation occurred after the nineth interview. However, inspite of this, a total of fourteen women were interviewed.

Data analysis process

Each oral history was submitted to a process of transcription, carried out in three steps. The transformation of tape recorded data into a written language was the first step. The textualization of narrative, with the omission of research questions, was the second step. During this work, the keywords for each narrative were identified, the central ideas established, and a "vital tone" selected. This refers to 
a sentence that reveals the essence of the narrative. The extraction of a vital tone of each history is essential to preserve the contribution of individual collaborators, and to give them a voice. Collaborators have confirmed the respective vital tones in order to respect the oral history statute prerogative. The last step of the transcription process was the transcreation, or the finalization of the text. This results in the final version of the narrative. A deep immersion in each transcribed narrative, through successive readings of each recorded speech, has permitted the narrative's analysis process ${ }^{(7)}$.

This process was carried out in an inductive way. During this work it was possible to discover different meanings and expressions related to health and illness care practices in order to permit the construction of descriptive categories. The extraction of quotes from narratives was used as a measure to make the descriptions more real. Finally, each narrative was read once again. It was possible to verify the absence of contradiction between the oral histories and the descriptive categories. This iterative data analysis is considered a significant feature to assure research validity and to make qualitative research a systematic and rigorous process ${ }^{(8)}$.

Research ethics aspects were in accordance with the Brazilian National Health Council criteria ${ }^{(9)}$. A research-participation consent form was signed by all collaborators after receiving detailed information about the research and the anonymity guaranteed by utilization of fictitious names.

\section{FINDINGS}

The personal characteristics of the women, the vital tones, the descriptive categories and related contents are presented.

Personal characteristics of the women

The women ranged in age from 25 and 70 years (average of 45 years), ten were married, three were divorced and one was a widow. The time they had resided in the community varied from 10 to 30 years (average of 17 years). Regarding employment, nine worked away from home, and among these seven were supporting the family whilst five took care of the household. Twelve women had four years of formal education and two were illiterate. When questioned about religion, seven were Evangelical Christians, six were Catholic and one was a Spiritist. All women were Brazilian.

The vital tones

Fictitious names, chosen from typical Brazilian flora, were utilized to identify the women.

I make due as I can because when a poor person goes to a physician, she is treated carelessly (Gerânio).

Medicine doesn't have a cure for incurable disease, but Jesus does (Junípero).

We treat colds with home remedies but pneumonia requires the help of a physician (Camomila)

Known diseases aren't dangerous, we treat them at home, but unknown diseases are dangerous, we need to see a physician (Manjerona).

First I seek help from God, then I use herbs and, finally, I ask for a doctor (Tomilho).

A poor person never has enough money to buy medicines, so the herbs are better (Cedro).

To go to the hospital requires time and money. So, I prefer to stay with Jesus (Alecrim).

Folk remedies are better. I ask for physicians only when I don't know the disease (Salvia).

I went to the doctor, he gave me a remedy, but I thought: I have a better remedy at home (Mentruz).

Herbs are my medicine, I don't buy pharmaceutical products. Thank God, I'm very well. People who have faith conquer all, including diseases (Hortelã).

I'm an old hand at using herbs, I heal myself with herbs, but only God does the healing (Aloe Vera).

I took medicine, but I no longer believe in medicine. So, I put my trust in Jesus (Erva Doce).

First, I apply my knowledge of herbs and healing. If the disease persists, I seek medical care (Urucum).

Because of what happened to me, I have a negative opinion of physicians. I'm afraid of doctors (Picão).

The descriptive categories

- The poor person has an own way to take care related to health and illness

Women learn to deal with the health-illness process based on their own poverty lived experiences. Poverty is perceived by women as a stigma and is incorporated in their health/illness behaviors, and consequently it permeates their health/illness care decisions and actions. 
For these women, the maintenance of health has an important and specific value. It represents the possibility of giving continuity to the working activity and it is essential for the immediate personal and family survival. Signs of illness provoke anxiety because the health condition represents the capacity to fight for life. Usually, women do unregistered menial jobs, like home cleaning which require a good physical and mental disposition.

Health is so important for us. I've taken my lumps, but I'll never give up, never. Fatigue, illness, lack of money, nothing can defeat me. With this strength, you won't lose...This energy is very important for our survival. I always take care of my health, to continue to live and fight. I learned to live humbly, preserving myself from illness.

Physical and mental health preservation is considered a main aspect of women's life. Nevertheless, the necessary preventive health care practice, like a gynecological cancer exam, isn't usually taken by women. They consider themselves as "lax" in this aspect of life. Priority of care is directed to the other family members, mainly to the child. According to the women's own point of view, a child with a disease is a consequence of mothers' carelessness.

Health is important, but I don't take enough care of myself, I don't do the Pap's smear periodically, for example, because I'm lax. But I do everything for my children, I have to be a good mother. As far as I'm concerned, I'm unimportant.

Women maintain a constant state of alert in relation to their own vulnerabilities, mainly in relation to health preservation. The women associate the anxiety condition with their strong poverty reality. Mental health promotion opportunities are few and restricted to the dialogue with friends, godmothers and neighbors, to watch television and to go to church. These resources are considered a way to share daily problems but valued as improper for personal conflict resolutions. They resort to a variety of strategies of self-help improvement.

Low socioeconomic conditions and gender oppression affect womens' mental health because they cannot see how to overcome these problems. Consequently, women must deal with the traumas originated from them. With the aim of obtaining wellbeing, the out-of-control personal, family and social conflicts are confronted in several ways. Women ask for self-medications and to do many other things in order to try to overcome and to promote selfcare. But, the main support is represented by faith because, for women, God represents the safeguard for all confronted problems.

The poor person has her own way to confront illness... When I'm sad or anxious, I take an aspirin, I talk with others and start feeling better... When I feel I'm becoming depressed, I sing, bake a cake and come out of this bad mood... God is one way of caring for health, the head, every problem.

Signs of illness are immediately confronted. All folk care knowledge is put in practice in order to avoid medical care.

With some wounds, I wrap a red cloth on the place because red helps the body to heat up and defend itself better, I brew tea, sympathetic magic, everything together, so as not to have to go to the hospital.

Knowledge of folk care practices such as herb remedies, sympathetic magic, effects of a variety of teas are shared among the neighbors and relatives. The easy access for many different herbs, plants and other healing resources, give to them a sense of security. Efforts are made to maintain an easy accessibility to a variety of illness related care resources. The older women are considered references in terms of knowledge related to the herbs, healing effects and other care practices. This scope of knowledge is transmitted from one generation to the next in family and neighborhood context.

- The main support to fight the illness is the belief in God

The belied in God is the womens' most important support to fight the illness condition. It constitutes the guide for the preservation of life and to direct their own health condition into a good way. The opposite behavior, or the lack of faith and the belief in God's power is considered a harm and valued as the cause of the illness and life's malevolent occurrences. Simultaneous measures are taken in order to combat the illness' signs and symptoms. When an illness condition is apparent and needs to be faced, women first ask for spiritual power, then the aid of herbs and other healing practices and, lastly, the search for medical care. Medicine, physicians and other health professionals are also seen as having a divine attribute. Spirituality represents to the women an indispensable support for their medical care success.

The strength to face difficulties comes from faith. Lack of faith provokes evil... I first look for help from God, then from the herbs. The doctors and pharmaceutical medicines also help. 
Everything together... When God wants, He also uses the doctors... God provides essential support in all illness cases

- Medical care is the last resource, when healing resources are not enough and the illness is dangerous

Home caregivers perform an evaluation of the severity of the illness. In this way, they establish a distinction between "dangerous" and "nondangerous" health disorders. Unknown illness conditions are classified as "dangerous" and familiar ones aren't.

When the caregivers perceive the ineffectiveness of healing practices, including the use of herbs, they become very anxious. They then do an accurate analysis of all factors involved in the situation. The severity, as well as the risk of complications due to the illness condition is evaluated. After consideration and evaluation of all involved factors, the lack of experience with the signs and symptoms of the illness is mainly considered. Poor knowledge about what is happening with the sick person is the determinant factor in the decision making process related to whether or not to obtain medical health care at an institution.

When the symptoms are clearly recognized, the process of choice between home healing practices and professional care is fast and easily decided upon. When all home healing care possibilities are exhaustively practiced and the illness condition persists, the health institution is visualized as the last possibility for treatment.

When an illness is known, it isn't danger, we have the knowledge to combat it. An unknown illness is a problem because it can be dangerous. In all cases, we use our own knowledge to try to cure it. A bone fracture is a case for medical care. When we can't handle the treatment, we go to a physician.

The process of seeking out a health care institution is preceded by a detailed evaluation of medical care costs and benefits. Financial factors, including the need for transportation that requires money or other financial support, the time availability as well as the need to attend to household chores are some items considered in the decision making process. The personal experiences of the women in regard to the health institution and professional care effectiveness are also analyzed. Negative evaluation attributed to the public health care system is considered in the evaluation process. Such negative impressions include their previous experience of care received from hospital staff and health care professionals.

There's the financial question of medicines and transportation expenses. It is cheaper with herbs. If you belong to the lowest social class, it's a discrimination after another. So, I prefer to do health care at home in case of illness. I, with God's help... People from a weaker class such as ours, they think we're just nobody. I feel great fear when I have to go to the doctor. I go only when I'm really very ill. The public health institutions are always on strike... the line is too long.

The women have the belief that pharmaceutical medicines provoke collateral and dangerous effects. This belief contributes towards the women's choice to use folk care knowledge.

The doctor gave me an antibiotic to cure the urine infection. But I believed that antibiotics might be harmful...I've got a better remedy at home.

In addition, there is a belief that medicine is only useful in combating symptoms. The women perceive a lack of consideration of professionals regarding their socioeconomic and cultural background. According to their personal experience, the professionals prescribe the use of medicines and other medical treatment without any regard and consideration for the socioeconomic conditions of the women concerned.

Doctors don't ask if you have money or not to buy the remedies. They consider it as a problem of the user. Usually we don't have financial resources to buy remedies. The doctors give prescriptions, but the poor never have the money to buy them, so it's easier to turn to the herbs.

\section{DISCUSSION AND IMPLICATIONS FOR NURSING CARE}

The women included in this study consider themselves as "poor" and have learned, since their childhood, to establish social relationships like poor persons. During infancy primary socialization occurs and the structure of a person's character is constituted. Simultaneously, the personal, family and social behavior models, including the health-illness related ones are structured. Health professionals must recognize that during primary socialization, life experiences are incorporated in an emotional way ${ }^{(10)}$. The consequences of poverty, such as stigma, inferiority and oppression suffered during childhood, continue to be present at a subconscious level into adulthood. It is a situation that affects human attitudes, 
including health-illness related ones. To understand the connection of personal experiences with present behavior and how it is addressed by a person represents a great challenge for health professionals.

Cross-cultural communication will only begin to improve when health professionals recognize the meaning of their own individual attitudes. A greater understanding of others can be established only when health professionals increase their own selfawareness $^{(11)}$. For nurses and other health professionals, creative resources to facilitate and to mobilize socially available resources need to be incorporated in health care planning and implementation ${ }^{(12)}$.

A great importance in regard to spirituality was observed among women living in Rio Negro. Religion has a major impact on the health care and life style, and studies aimed at developing knowledge about this topic are required, especially in low-income contexts ${ }^{(13)}$. In this aspect, nurses and other health care providers should integrate scientific, religious, and cultural knowledge into their clinical practice. It is considered essential for promoting quality of life of families ${ }^{(14)}$.

This factor and any other influencing popular social and cultural health related actions need to be understood, analyzed and primarily considered in health care projects proposed by professionals and public policy. Home care nurses and their supervisors need to develop their skills with the aim of offering culturally competent health care. This challenge requires a culturally oriented patient assessment, staff development educational programs and the adoption of an organizational policy to expand culturally diverse client base support for easy use by home care agencies ${ }^{(15)}$.
The family's power to chose become more restricted when a member is sick and the family members are affected as a result of the condition they have to face. The experience of sickness, as well as the condition of vulnerability confronted in this situation, need to be understood by health professionals in a deep and comprehensive way. This knowledge is essential for the proposition of adequate care of families confronting serious situations $^{(16)}$

Research on the health-illness process in specific cultures has important value. Research findings can describe how social and cultural conditions influence behavior in the health sphere. The research also clarifies the complex relationship regarding socio-economic conditions, geographic localization, attitudes related to health and illness and the reasons that establish these decisions and behaviors.

In low-income settings the social sphere is intrinsically associated with cultural background and these factors need to be considered in health care management. One aim of this research was to offer to those who do not normally have a voice, the opportunity to express their opinions. This is one of the main purposes of oral history research ${ }^{(7)}$ The health of a nation's people is the cornerstone of its economic development. The poor of the world cannot be neglected ${ }^{(17)}$. The knowledge about the strong and complex factors involved in the health care practices and decisions in low income families can support health professionals' actions in order to satisfy the real health care needs of the people they serve.

\section{REFERENCES}

1. Ministério da Saúde (BR). O sistema público de saúde brasileiro. Brasília (DF): Ministério da Saúde; 2002.

2. Vasconcelos EM. A medicina e o pobre. São Paulo (SP): Paulinas; 1987.

3. Ferreira J. Cuidados do corpo em vila de classe popular. In: Duarte LFD, Leal OF. organizadores. Doença, sofrimento, perturbação: perspectivas etnográficas. Rio de Janeiro (RJ): Fiocruz; 1998. p. 49-56.

4. Frank AW. When body need voices. In: Frank AF, organizator. The wounded storyteller - body, illness and ethics. Chicago (BO): University of Chicago Press; 1995. p. 24-61.

5. Moreno EC, Martín MF, Uriel RG. Aplicación de la mirada antropológica en la disciplina enfermera. Index Enfermería 2003 mayo; $12(43): 37-9$.
6. Angelo M, Bousso RS. Fundamentos da assistência à família em saúde. In: Instituto Para o Desenvolvimento da Saúde (SP), Universidade de São Paulo (SP), Ministério da Saúde $(B R)$, organizadores. Programa de saúde da família - manual de enfermagem. São Paulo (SP): IPDS/USP/MS/Fundação Telefônica; 2001. p. 14-7.

7. Bom Meihy JCS. Manual de história oral. São Paulo (SP): Loyola; 1996.

8. Meadows LM, Morse JM. Constructing evidence within the qualitative project. In: Morse JM, Swanson JM, Kuzel AJ, editors. The nature of qualitative evidence. Los Angeles (CA): Sage; 2001. p. 187-200.

9. Ministério da Saúde (BR). Diretrizes e normas regulamentadoras de pesquisa em seres humanos. Brasília (DF): Ministério da Saúde; 1997.

10. Berger PL, Luckmann $\mathrm{T}$. The social construction of reality. New York (NY): Doubleday; 1966. 
11. Elliot AC. Health care ethics: cultural relativity of autonomy. J Transcult Nurs 2001 October; 12(4):326-30.

12. Valla VV, Stotz EN. Educação, saúde e cidadania. Petrópolis (RJ): Vozes; 1994.

13. Montero P. Da doença à desordem: a magia da umbanda. Rio de Janeiro (RJ): Graal; 1985.

14. Subgranon R, Lund DA. Maintaining caregiving at home: a culturally sensitive grounded theory of providing care in Thailand. J Transcult Nurs 2000 July; 11(3):166-73.

15. Dicicco-Bloom B, Cohen D. Home care nurses: a study of the occurrence of culturally competent care. J Transcult Nurs 2003 January; 14(1):25-31.

16. Pettengil MAM; Angelo M. Vulnerabilidade da família: desenvolvimento do conceito. Rev Latino-am Enfermagem 2005 novembro/dezembro; 13(6):982-8.

17. Kraatz ES. The structure of health and illness in a Brazilian favela. J Transcult Nurs 2001 July; 12(3):173-9. 